\title{
THE RIGHT TO MEDICAL ASSISTANCE FOR DRUG ADDICTS: EXAMINATION OF THE PROBLEM
}

DOI: 10.36740/WLek202012237

\author{
Inna K. Polkhovska, Anna S. Sydorenko, Olena D. Melnyk \\ ${ }^{1}$ POLTAVA LAW INSTITUTE OF YAROSLAV MUDRYI NATIONAL LAW UNIVERSITY, POLTAVA, UKRAINE
}

\begin{abstract}
The aim: The purpose of this article is to conduct a thorough review and assessment of the exercise of the right to medical care for drug addicts, in particular in custody, through the analysis of international acts and strategies in the fight against drug addiction, as well as drug policies of individual States.

Materials and methods: The study is based on the analysis of international documents, the drug control strategies, the case law of the European Court of Human Rights and analytical researches in this area. The article is based on dialectical, system and structural, comparative and legal methods, the method of analysis and synthesis.

Conclusions: Ensuring human rights without any discrimination should be a priority in the politics of modern States. The implementation of prevention and rehabilitation programs based on scientific evidence is also important. The current situation, in which persons who use drugs experience significant restrictions of their rights and freedoms, is unacceptable.
\end{abstract}

KEY WORDS: drug abuse, drug addicts, drug policy, treatment of drug addicts, custody

Wiad Lek. 2020;73(12 p. II):2927-2933

\section{INTRODUCTION}

The UN General Assembly decided in the year 1987 to celebrate June 26 as the International Day against Drug Abuse annually to mark the determination to create a drug-free society. Despite the long-term efforts of the international community and the policies of individual States in the fight against drugs, the world continues to witness an alarming trend of growing number of drug addicts. Based on multiyear studies UN have concluded that a country with more than $7 \%$ of the population using drugs is doomed. Such a State has no future. 35 million people worldwide suffer from drug-related disorders and need treatment according to the 2019 World Drug Report. 17.4 million people inject drugs. Almost every eighth injecting drug addict has HIV [1]. The number of people in the European region who use drugs at least once a year is about 275 million, or about $5.6 \%$ of the world's population aged $15-64$. Every $4^{\text {th }}$ person in the European Union has used drugs at least once in his (her) life according to the European Monitoring Center for Drugs and Drug Addiction. Citizens of the European Union spend about 24 billion euro on illicit drugs annually [2]. Such data show the global drug problem and should encourage the need for greater international cooperation to ensure integrated action in the area of health and criminal justice.

The United Nations Office on Drugs and Crime (UNODC), in particular the Commission on Narcotic Drugs, as the decision-making body of the UN system responsible for drug control, adopted in 2019 in Vienna Ministerial declaration on strengthening concerted actions at the national, regional and international levels to accelerate the implementation of joint commitments to address and counter the world drug problem. The declaration, among the commitments to address health problems arising from drug abuse, emphasizes the new challenges associated with the global drug problem in the world: expansion and diversification of the range and market of drugs, illegal demand for chemicals, growth of organized crime, in particular trafficking in human beings, illicit trafficking in firearms, cybercrime, in some cases terrorism, money laundering obtained from illicit drug trafficking. It is also a large set of health-related problems: drug services and health care system do not meet the necessary requirements; drug-related mortality rates are increasing; many countries have high rates of HIV, hepatitis $\mathrm{C}$ and other blood-borne infections; the harmful effects and health risks associated with the use of new psychoactive substances have reached alarming levels; synthetic opioids and the use of medicinal substances for non-medical purposes are a real threat to health and safety of the population, as well as the cause of complex tasks of scientific and regulatory content, in particular in determination of the status of substances list. And the legal supply of substances for medical and scientific use, including pain relief and palliative care, remains low or not existing in many parts of the world.

\section{THE AIM}

The purpose of this article is to conduct a thorough review and assessment of the exercise of the right to medical care 
for drug addicts, in particular in custody, through the analysis of international acts and strategies in the fight against drug addiction, as well as drug policies of individual States.

\section{MATERIALS AND METHODS}

European Convention on Human Rights; Maltese Declaration of the World Medical Association; international documents of the United Nations and the World Health Organization, in particular the UN Convention on Narcotic Drugs, UNODC Regional Programme for South Eastern Europe (2020 - 2023); European penitentiary rules; data from the European Monitoring Center for Drugs and Drug Addiction and the International Drug Policy Consortium for 2018; World Drug Report 2019; the EU Drug Strategy for the period 2013 - 2020; decisions of the European Court of Human Rights.

The methodology of research and achievement of results is based on a set of general and special methods of cognition: dialectical, system-structural, comparative-legal, methods of analysis and synthesis.

\section{REVIEW AND DISCUSSION}

Drug abuse is a socially dangerous phenomenon and a particularly serious disease that negatively affects a person's relationship with the outside world. Drug abuse is considered a disease that requires appropriate treatment. For the most part, drug addicts belong to so-called "vulnerable groups" in terms of health and lifestyle. Vulnerable individuals and groups are categories of persons who for various reasons are restricted on the capacity to independently perform fundamental human and civil rights and freedoms and therefore need assistance to meet their basic physiological and social needs, as well as the rights and interests of both property and personal non-property character [4].

According to the Single Conventions on Narcotic Drugs of 1961 and UN Convention against Illicit Traffic in Narcotic Drugs and Psychotropic Substances of 1988, other documents in this area, the main task of the drug control system is to ensure health and well-being of mankind. Human rights and freedoms follow from the recognition of dignity and value of the individual. They are universal and integral, and a person cannot be deprived of them on the ground that he or she is using drugs or is HIV-positive. At the time, UN High Commissioner for Human Rights Navanethem Pillay noted that "drug users should not be deprived of any rights".

Instead, drug addicts are usually subject to harassment, violations of their rights, and often by law enforcement agencies. The most typical situations are: violation of the right to freedom from torture, ill-treatment and inhuman treatment in connection with arbitrary detention of drug users and abuse in compulsory drug treatment centers $[6 ; 7 ; 8]$; violation of the right to health due to restriction of access to essential medicines, prevention, treatment, care and support for people living with HIV/AIDS; violation of the right to life in the application of death penalty or extrajudicial execution for drug-related crimes (more than 30 countries apply death penalty for drug-related crimes) [9]; violation of the right to freedom from slavery, as some compulsory drug treatment centres use forced labor, etc. The most ill-treated are drug addicts who end up in custody - in places of temporary detention, restriction or imprisonment. Most people who are in custody can be categorized as very poor because they use psychotropic substances and have physical and mental disorders, i.e. need treatment. Instead, the conditions of their custody do not meet the established standards; their right to adequate medical care and health care is not respected and is a dominant factor in the relationship between prisoners and staff, which in turn leads to violence and abuse with regard to these people. It should be agreed that such persons often find themselves in conditions that further pose a threat to their rights, including in the granting of proper medical care [10].

A. Kamarunzaman and J.L. McBreyer and a number of international organizations point out that drug addicts face high levels of stigmatization and discrimination when accessing medical facilities for assistance. They are denied medical care while in detention, where they become victims of humiliation, physical and psychological violence [11]. In turn, the members of the International Drug Policy Consortium conclude that in 2018 in most countries people who use drugs become victims of institutional violence, stigmatization and discrimination [12].

Any person, regardless of his (her) specific characteristics, has equal rights and freedoms, as well as equal opportunities for their implementation in accordance with generally accepted principles and norms of international law. Any forms of discrimination on the part of State bodies, their officials, legal entities under public and private law, as well as individuals are prohibited. The standard of proper conduct is enshrined in Art. 3 of the European Convention on Human Rights, according to which: "No one shall be subjected to torture or to inhuman or degrading treatment or punishment". One of the fundamental decisions of the ECtHR states that Art. 3 of the Convention is the embodiment of the fundamental values of democratic societies that are part of the Council of Europe and is considered one of the most important fundamental provisions of the Convention, from which no derogation is permitted (Selmuni v. France [13]). According to the Court, the conduct was "degrading" if it was intended to provoke feelings of fear, torment and inferiority on the victims and thus to humiliate and insult them (Kudla v. Poland [14]). So the failure to provide adequate medical care to drug addicts in temporary detention facilities, places of deprivation and restriction of liberty during the withdrawal syndrome is nothing more than torture and violation of the provisions of the Convention.

The European Union has adopted a single approach in the fight against drug addiction, which is reflected in the Drug Strategy for the period 2013 - 2020. The main emphasis in this document is placed on the measures of medical and social response to this problem. Such measures should, first of all, ensure the person's right to the highest 
level of physical and mental health, as well as appropriate treatment; secondly, provide equal access to such treatment [15]. In turn, the World Health Organization has adopted European health policy framework "Health - 2020" to improve health and reduce inequalities among people in need of health care. It states that social values and human rights are crucial in the area of health care, which can be achieved, first of all, by increasing the level of well-being of the population and reducing inequalities in the issue of receiving adequate medical care. These provisions should operate and apply to persons in places of temporary detention, restriction or imprisonment. [16].

The main problem now is that many countries do not ensure proper discharge of their responsibilities for health care, assistance, and creation of proper conditions for treatment of persons, including drug addicts, in correctional institutions. The expert group advising the Regional Office on the organization of prison health once drew attention to this problem and determined that the responsibility for ensuring the health of persons in such institutions should be assigned to State authorities; the ministries of health and their structural units should provide medical services and appropriate care; protection and human rights, including to health care, must be respected; standards of care should be based on those provided to persons, who are not under detention.

International organizations have adopted a number of regulations, rules, conventions and recommendations, practical manuals, which focus on the fight against drug abuse, health care and treatment of drug abuse and the responsibilities of penitentiary services, medical services operating in such institutions, medical facilities for the provision of appropriate medical care and rehabilitation. For example, the World Health Organization along with the United Nations Office, has developed a "Good governance for prison health in the 21st century: A policy brief on the organization of prison health", which enshrines the basic rights of detainees and convicts, as well as the responsibilities of medical services: the right to health care; provision of preventive, ethical and technical standards by medical services; such services should only provide medical care and not be involved in the enforcement of sentences; medical services should be integrated into national health systems and policies, including active participation in training, professional development, especially in the context of working with prisoners [17]. However, it should be emphasized that assigning responsibilities exclusively to healthcare professionals in penitentiary institutions in matters of health care is not quite right, as other employees of such institutions have to be able to provide first aid, and therefore must undergo appropriate training. The European Prison Rules describe the specifics of providing medical care to persons in need, including drug addicts. Thus, these rules recommend each penitentiary institution to have at least one qualified general practitioner and other medical staff who obtained an appropriate level of medical training (par. 41.4); a doctor or a qualified nurse should examine each prisoner as soon as possible (par. 42.1); every prisoner should be able to receive treatment in case of withdrawal syndrome because of the abuse of drugs, psychotropic substances or alcohol (par. 42.3.d); it is recommended to transfer prisoners in need of special treatment and prisoners with mental disorders (par. 47) to specialized institutions or civilian hospitals, if such treatment is not possible within penitentiary institutions (par. 46.1) [18].

The Maltese Declaration of the World Medical Association determines the main responsibilities of doctors and other health professionals working in penitentiary institutions, the main of which are: such entities must act in accordance with the rules of medical ethics; make efforts to prevent involuntary and inappropriate treatment; conduct an examination of the patient's mental characteristics; do a full examination [19]. That is, the activities of health professionals should be primarily focused on the fact that they work according to the principle "doctor - patient". The persons in places of deprivation and restriction of liberty should be able to exercise their right of access to health care at any time and receive appropriate treatment at the same level as individuals, who are not under detention. All health professionals in correctional facilities should understand that their primary responsibility to those in such facilities is to provide adequate and qualified medical assistance. This duty is also enshrined in the United Nations Principles of Medical Ethics, which stipulate that persons obliged to provide medical care to detainees and convicts should protect the latter against torture and other cruel, inhuman or degrading treatment or punishment. States parties are encouraged to oblige health personnel, particularly physicians, charged with the medical care of prisoners and detainees have a duty to provide them with protection of their physical and mental health [20, p.438].

Attention should be paid to the publication of the European Monitoring Center for Drugs and Drug Addiction "Health and social responses to drug problems" to address the issue of receiving proper medical care for drug addicts in correctional facilities. The paper places the emphasis on the fact that persons falling into criminal justice system demonstrate higher rates of drug use and therefore there is a necessity to meet their complex medical needs. That is, it is necessary to provide all relevant services for prevention and treatment of drug abuse. We are talking about opioid replacement therapy and detoxification [21, p.130]. The researchers on opioid substitution therapy concluded that drug addiction is a serious disease and every professional should play his (her) part in ensuring that prisoners are properly treated and the drug-related harm is minimized. However, in turn, they stress that this form of treatment is insufficient in correctional facilities [22].

The joint position of the World Health Organization and the United Nations Office on Drugs and Crime is that substitution therapy is an effective, safe and cost-effective treatment for opioid dependence [23]. The patient is regularly prescribed heavy drug substitutes under the supervision of doctors as part of substitution therapy. Typically, these drugs contain active substances such as methadone or, more often, buprenorphine. The prescription of substitution therapy and distribution of opioid agonists to opioid 
addicts for the use in officially recognized medical practice, approved by the competent authorities do not contradict the provisions of Single Conventions on Narcotic Drugs of 1961 and the Convention on Psychotropic Substances of 1971. Substitution therapy has successfully been introduced in the United States since the 1970s; it has widely been used in Europe since the 1990s. In Germany alone, the government spends to ten billion euro a year on drug prevention and treatment. Nowadays, more than 600,000 clients are involved in substitution therapy programs worldwide. The largest number of them are in the United States (about 200 000), and in the European countries (up to 400 000). Substitution therapy is used in Lithuania, Latvia, Estonia and Kyrgyzstan, Kazakhstan, Georgia, and Belarus. Supportive care is also successfully carried out in Asian countries: Iran, China, and Thailand. By the way, Iran, an Islamic country, in which even the use of narcotic drugs is subject to the death penalty, has demonstrated full support for such programs [24].

However, the 2019 World Drug Report states that 46 countries have claimed that there is no such treatment option in their penitentiaries. Effective treatment in accordance with international human rights obligations is not sufficiently available [1]. For example, methadone is included in the list of drugs banned from circulation in Russia. This substance is also banned in the Republic of Crimea after the occupation of the peninsula. A year after the ban on the use of methadone in Crimea, UN special envoy for HIV / AIDS in Eastern Europe and Central Asia Michel Kazachkin noted that dozens of patients, who had previously been in substitution therapy, died. Over 100 of 805 patients died. Most of them returned to drug use and were prosecuted. Those, who illegally kept methadone at home in attempt to escape punishment, were imprisoned. Besides, 200 patients of the 805 were HIV-positive [25]. In 2019, the European Court of Human Rights refused to satisfy the complaint of Russians I. Abdyusheva, I. Anoshkin and O. Kurmanaievskyi, which they filed against the Russian Federation on the ground that Russian hospitals, where they were treated for drug addiction, refused to prescribe methadone and buprenorphine, which are used as substitution therapy in some States (Abdyusheva and Others v. Russia). In taking the decision, the Court was guided by the argument that the use of methadone and buprenorphine was not a treatment for drug abuse but the replacement of one addiction with another one, as the effects of these drugs is incompatible with those of heroin. Although substitution therapy is widely used in some countries falling within the scope of the ECtHR, its effectiveness is considered controversial [26]. Thus, today there is no single approach to the use of substitution therapy in the treatment of drug addicts despite scientifically proven facts and tested positive results of its application. Sometimes it leads to gross human rights violations and irreversible consequences.

It should be noted that most places of detention and imprisonment cannot provide adequate medical care and treatment. Besides, this form of therapy in the above places is simply not available. As for detoxification, it can be in the form of both individual and group consultation. Detoxification should be provided with appropriate control over this procedure. If the patient is undergoing a severe crisis, symptomatic treatment of withdrawal syndrome can be included, including for monitoring the relevant symptoms [21, p. 133].

Health and Social Response to Drug Addiction emphasizes that there is often partnership between health services operating in places of deprivation and restriction of liberty and drug care organizations that allow provide continuous treatment in most European countries [21, p. 130].

Besides, the experts found various alternatives to punishment that can be used at different stages of criminal proceedings in the abovementioned publication of the European Monitoring Center for Drug Abuse - from arrest to sentencing for drug addicts, namely: prevention and inaction; distraction; creation and active work of committees to combat drug abuse; suspension of investigation or prosecution with elements of treatment; a stay of execution of the sentence with the elements of treatment; creation of a separate judicial body to hear cases related only to drugs; drug treatment; conditions for convicts with the elements of treatment; restriction of liberty with the elements of treatment; alternating imprisonment and release with the elements of treatment; conditional release with the elements of treatment [21, pp.131 - 132]. The above alternatives are relevant in determining the treatment of drug addicts in correctional facilities, but in our opinion it is unlikely that penitentiary services, courts and health care facilities will take responsibility for the use of such alternatives. But in the future the relations regarding the provision of appropriate medical care to persons who use drugs, psychotropic substances and their precursors, and, where necessary, the replacement of detention and deprivation of liberty with the possibility of receiving medical care and treatment in special medical institutions, should be established between ministries of health, their units and penitentiaries of all countries. Unfortunately, nowadays, people in penitentiary institutions do not exercise their right to health care at the appropriate level, because there is an insufficient level of medical care in most countries of the world, especially in relation to drug addicts, although proper health care plays an important role in alleviating suffering of such persons.

Thus, international organizations, non-governmental organizations and movements, which try to overcome the problem of drug abuse, are actively working on providing relevant assistance to combat drug addiction. However, the key role in resolving this issue belongs to the State, which can officially determine the direction of drug policy. The State should not violate, but protect human rights, including the rights of drug addicts. The commentary to the 1961 UN Convention on Narcotic Drugs notes that it is up to each State to determine the extent, to which it wishes to impose penalties for non-medical drug use or to give preference to drug prevention only through administrative and legal measures against cultivation, production and dis- 
tribution of drugs [27]. The analysis of foreign legislation and measures to combat drug trafficking in the European Union and the United States shows a gradual transition of these countries from the policy of "war on drugs" while disseminating the following concepts of harm reduction from non-medical drug use: introduction of substitution maintenance therapy; decriminalization of certain types of acts for minor misdemeanors; replacement of imprisonment for drug addicts by more lenient punishments, etc. [28, p. 7].

The main tasks of the drug policy of modern States should be health care, which includes expanding access to medicine, development of harm reduction programs and programs of prevention, treatment, care and support; providing support in the area of alternative development, as well as poverty reduction, education opportunities, employment issues, social security, etc.; human security, as the efforts of law enforcement agencies should be aimed primarily at identifying those who cause the most serious problems related to drugs, and not only those who are small-time dealers $[28$, p. 8$]$.

The United Nations Office on Drugs and Crime (UNODC) is proposing to build on its current strategic multi-sectoral approach in South Eastern Europe in the four-year period 2020 - 2023. This document outlines the principles, on which the Regional Programme for South Eastern Europe rests and the planned activities during the 2020 - 2023 programming cycle. The current document also analyzes the linkages between the UNODC work and the Sustainable Development Goals and the 2030 Agenda for Sustainable Development, to which all United Nations bodies and agencies aim to contribute, as well as sets these important parameters against the background of the current situation in the region in areas relevant to UNODC's mandate ad-dressing the interconnected challenges to security, rule of law and health). South Eastern Europe lies on the most direct route between some of the world's leading producer and consumer regions of opiates, and likewise serves as a transit corridor for migrants and refugees from Asia and the Middle East to Western Europe; it saw one of the world's largest population movements in 2015 - 2016, as well as an influx of foreign terrorist fighters. These features highlight the challenges faced by the governments of the region in controlling their borders and fighting the smuggling of migrants as well as that of drugs, weapons, and other illicit goods [29, p.8].

Among the important steps envisaged by this plan are: enable relevant national counterparts and line Ministries to develop and implement evidence-based interventions and policies in family settings as well as in school and community settings (including workplace; support evaluation of the effectiveness of interventions and policies, including related data collection, research and reporting, by relevant counterparts and mainstream it in strategic documents. Besides, to promote, develop and utilize evidence-based treatment modalities and interventions to en-hance national capacities and assure greater quality of services; support national professionals and policy-makers in developing strategic documents and technical tools and in conducting relevant assessments of treatment of drug use disorders, including monitoring and evaluation, to adequately track trends and identify corrective measures; support evaluation of the effectiveness of intervention sand policies, including related data collection, research and reporting, by relevant counterparts and mainstream in strategic documents [29, p. 82].

According to the new agenda for sustainable development for the period of 2016 - 2030 - Sustainable Development Goals, humanity has committed itself to ending epidemics of AIDS, tuberculosis, malaria and tropical diseases that are not given due attention, and to ensure the fight against hepatitis, water-borne diseases and other infectious diseases (par. 3.3), as well as to improve the prevention and treatment of substance abuse, including drug and alcohol abuse (par. 3.5). Such commitments must be a priority in the policies of modern nations to end the world's drug pandemic, and thus to improve health, safety and quality of life of the population.

\section{CONCLUSIONS}

Based on the above-stated, we can conclude that guaranteeing and ensuring human rights without any discrimination should be a priority in the politics of modern States. The drug policy of States to support drug addicts is the basis for finding the solution to the problem of drug abuse. The implementation of prevention and rehabilitation programs based on scientific evidence is also important. Besides, the current situation, in which persons who use drugs experience significant restrictions of their rights and freedoms, is unacceptable.

Drug addicts who are in places of detention have a guaranteed right to an adequate level of medical care and treatment without any discrimination; quality medical assistance regardless of the detention regime; receiving medicine, rehabilitation, prevention; due attention and professional doctors' attitude in accordance with international legal standards. All health professionals must be independent in providing care and making professional decisions in relation to prisoners. After all, all persons in need of care, regardless of their location, mental and health state of, are first and foremost patients who have the right to proper medical assistance.

\section{REFERENCES}

1. Vsemirnyy doklad o narkotikakh. Upravleniye $00 \mathrm{~N}$ po narkotikam i prestupnosti [World Drug Report. United Nations Office on Drugs and Crime] (UNP 00N), 2019. Available from: https://www.unodc.org/ unodc/ru/frontpage/2019/June/world-drug-report-2019_-35-millionpeople-worldwide-suffer-from-drug-use-disorders-while-only-1-in-7people-receive-treatment.html [reviewed 2020.08.01] (Ru).

2. Narkozalezhnist - the khvoroba, a ne zlochyn. [Drug addiction is a disease, not a crime] Available from: https://www.phc.org.ua/news/ narkozalezhnist-ce-khvoroba-ne-zlochin [reviewed 2020.08.01] (Ua).

3. Strategic engagement with civil society on drugs. Available from:https:// www.unodc.org/unodc/en/ngos/drugs.html [reviewed 2020.08.01]. 
4. The Human Rights Protection of Vulnerable Groups. Human Rights Education Project.Icelandic Human Rights Centre. Available from: https://www.humanrights.is/en/human-rights-education-project/ human-rights-concepts-ideas-and-fora/the-human-rights-protectionof-vulnerable-groups/ [reviewed 2020.08.01].

5. High Commissioner calls for focus on human rights and harm reduction in international drug policy. United Nations Press Release,10 march 2009. Available from:http://www.unhchr.ch/huricane/huricane.nsf/ view01/3A5B668A4EE1BBC2C12575750055262E?opendocument [reviewed 2020.08.01].

6. Human rights abuses in the name of drug treatment, reports from the fiel. Open Society Institute \& International Harm Reduction Development Program, 2009. Available from: http://www.soros. org/initiatives/health/focus/ihrd/articles_publications/publications/ treatmentabuse_20090318/treatmentabuse_20090309.pdf[reviewed 2020.08.02]

7. Observations on the Narcotic Addict Rehabilitation Act B.E. 2545. Compulsory Drug Treatment in Thailand, 2002, (Canadian HIV/AIDS Legal Network). Available from:http://www.aidslaw.ca/publications/ publicationsdocEN.php?ref=917 [reviewed 2020.08.02].

8. Skin on the cable - The illegal arrest, arbitrary detention and torture of people who use drugs in Cambodia.Human Rights Watch, 2010. Available from: http://www.hrw.org/en/reports/2010/01/25/skincable-0[reviewed 2020.08.02].

9. Ten year drug strategy Review: Ten ways drug policy affects human rights. Human Rights Watch, Open Society Institute \& International Harm Reduction Association, UNGASS. Available from:http://www.ihra.net/Assets/1512/1/ UNGASSReviewFactSheetDrugPolicylHRAHumanRihtsWatchandOSI. pdf [reviewed 2020.08.02].

10. Ustoychivaya zhizn. YuNODK. Available from: http:// www.unode.org/ castasiaa_ndpasifie/en/topies/sustainable-livelihoods/index/html [reviewed 2020.08.02].

11. Kamarulzaman IDzh. L. Makbrayer Tsentry prinuditelnogo soderzhaniya dlya narkozavisimykh v Vostochoy I Yugo-Vostochnoy Azii. [Detention centers for drug addicts in East and Southeast Asia] Mezhdunarodnyy zhurnal narkopolitiki. 26 (1), fevral, 2015 : 33-37 (Ru).

12. Podvedeniye itogov: desyatiletiye narkopolitiki: tenevoy doklad grazhdanskogo obshchestva. Mezhdunarodnyy konsortsium po narkopolitike, [Taking stock: a decade of drug policy: a shadow report from civil society. International Consortium on Drug Policy] 2018. Available from: http://fileserver.idpc.net/library/Executive_Summary_ RU.pdf [reviewed 2020.08.03] (Ru).

13. Case of Selmuni v. France Available from: https://zakon.rada.gov.ua/ laws/show/980_374\#Text [reviewed 2020.08.03]

14. Case of Kudla v. Poland. Available from: http://eurocourt.in.ua/Article. asp?Aldx=327 [reviewed 2020.08.03].

15. EU Drugs Strategy (2013-2020) (2012/C402/01)/ Official Jornal: 402.

16. Zdorov'ya - 2020. Yevropeiska polityka okhorony zdorovia. [Health 2020. European health policy] Available from: http://euro.who.int/ health-topies/health-policy-2020 the-european-policy-for-healthand-well-being/about-health-2020 [reviewed 2020.08.04] (Ru).

17. Razumnoye strategicheskoye rukovodstvo okhranoy zdorovia v mestakh lisheniya svobody v XXI veke: kratkiy analiticheskiy obzor po voprosu organizatsii penitentsiarnogo zdravookhraneniya. [Smart health governance in prisons in the 21st century. Brief analytical review on the issue organizations of penitentiary health care] Vsemirnaya organizatsiya zdravookhraneniya, 2014. Available from: https://
www.euro.who.int/__data/assets/pdf_file/0009/247329/Goodgovernance-for-prison-health-in-the-21st-century-Rus.pdf [reviewed 2020.08.04] (Ru).

18. Yevropeiski penitentsiarni pravyla. Rekomendatsiia № R (2006)2 Komitetu Ministriv derzhav-uchasnyts. [European penitention rules (Recommendation № R (2006) 2 Committee of Ministers of the States Parties)] Available from: https://zakon.rada.gov.ua/laws/ show/994_032\#Text [reviewed 2020.08.04] (Ua).

19. Declaration on Hurger Strikers adopted by the $43 \mathrm{rd}$ World Medical Assembly Malta, November 1991 and revised by the World Medical Association General Assembly, Pilanesberg, South Africa, October 2006. Fluney-Voltaire, World Medical Association, 2013. Available from: https://www.wma.net/policies-post/wma-declaration-of-malta-onhunger-strikers/ [reviewed 2020.08.05].

20. Ugolkova E.I. Pravo osuzhdennykh k lisheniyu svobody na okhranu zdorovsia I meditsinskuyu pomoshch v mezhdunarodnykh aktakh. [The right of a convicted person to deprivation of liberty to health protection and medical assistance in international acts] Ugolovno-ispravitelnoye parvo, 2018;13 (1-4);4: 435-441. doi: 10.18287/2542-047X-2018-42-142-147 (Ru).

21. Mery meditsinskogo I sotsialnogo reagirovaniya na problemy narkomanii: Evropeyskoye rukovodstvo. [Medical and Social Responses to Drug Addiction: A European Guide] Otdel ofitsialnykh publikatsiy Evropeyskogo Soyuza. Evropeyskiy tsentr monitiringa narkotikov I narkomanii. Lyuksemburg, 2017. Available from: http://www. emedda.europa.eu/system/files/publications/6343/20174796_ TD0117699RUN_PDF/pdf [reviewed 2020.08.05] (Ru).

22. Andriy Kastelic, Jorg Pont, Heino Stover Opioidnaya zamestutelnaya terapiya v tyurmakh. [Opioid substitution therapy in prisons] All content following this page was uploaded by Heino Stover on 26.10.2018. Available from: http://www.researchgate.net./ publication/328530707opioidna_zamestitelnaa_terapia_v_turmah [reviewed 2020.08.05] (Ru).

23. Zamestitelnaya poddezhivayushchaya terapiya v vedenii patsiyentov s opioidnoy zavisimostyu I v profilaktike VICh-infektsii I SPIDa. [Substitution maintenance therapy; management of patients with opioid dependence and in the prevention of HIV and AIDS] Sovmestnaya pozitsiya VOZ/UOONNP/YuNEYDS, 2004. Available from: https://www. unodc.org/documents/russia//Reports/report_2004-03-15_1_ru.pdf [reviewed 2020.08.05] (Ru).

24. Zamisna pidtry'muval'na terapiya narkozalezhny'x v konteksti gromads'kogo zdorov'ya : perevagy ta nedoliky. [Substitution maintenance therapy for drug addicts in the context of public health: advantages and disadvantages] Available from: https://medcom.unba. org.ua/publications/publications/print/4133-zamisna-pidtrimuvalna-terapiya-narkozalezhnih-v-konteksti-gromads-kogo-zdorovyaperevagi-ta-nedoliki.html [reviewed 2020.08.05] (Ua).

25. Poryatunok narkozalezhnyx sprava ruk samyx narkozalezhnyx. [Saving drug addicts is the work of drug addicts themselves] Available from: https://krymsos.com/news/5e2568f663832/ [reviewed 2020.08.05] (Ua).

26. Abdyusheva and Othersv. Russia. Available from: https://www.hudoc.echr. coe.int/eng-press\#\{\%22itemid\%22:[\%22003-6572835-8702708\%22]\} [reviewed 2020.08.05]

27. Kommentarii k konvenciyam 00N. Kto zabotitsya o kontrole za narkotikami? [Comments on UN conventions. Who cares about drug control?] Available from: http://www.ecad.ru/oon/oon-kom.html [reviewed 2020.08.05] (Ru). 
28. Pytannia suchasnoi narcopolityky: prava liudyny ta dustup do likuvannia. [lssues of modern drug policy: human rights and access to treatment] Odeska pravozakhysna hrupa "Veritas". Kharkiv: Prava liudyny, 2011.91s. (Ru).

29. Regional Programme for South Eastern Europe2020-2023. UNODC. Available from: https://www.unodc.org/documents/ southeasterneurope//UNODC_SEE_RP_27-11-2019_final.pdf [reviewed 2020.08.06].

\section{ORCID and contributionship:}

Inna Polkhovska: 0000-0003-0998-4686 A,B,E

Anna Sydorenko: 0000-0002-3947-3863 B,D,F

Olena Melnyk: 0000-0001-5213-595X ${ }^{D, F}$

\section{Conflict of interest:}

The Authors declare no conflict of interest.

\section{CORRESPONDING AUTHOR}

Anna Sydorenko

Poltava Law Institute of Yaroslav Mudryi

National Law University, Poltava, Ukraine

tel: +380661540622

e-mail: gannusya1988@ukr.net

Recevied: 31.08 .2020

Accepted: 30.11 .2020

A - Work concept and design, B - Data collection and analysis, C - Responsibility for statistical analysis,

D -Writing the article, $\mathbf{E}$ - Critical review, $\mathbf{F}$ - Final approval of the article 